\title{
ANALISIS PEMBIAYAAN MUDHARABAH TERHADAP PENDAPATAN BANK SYARIAH DALAM PERSFEKTIF HUKUM EKONOMI ISLAM
}

\author{
Imam Sofi'i, Romenah \\ Fakultas Ekonomi Universitas Pamulang \\ imam_mpd@yahoo.co.id
}

Naskah diterima: 25 November 2021, direvisi: 30 November 2021, disetujui: 10 Desember 2021

$\overline{A b s t r a k}$

Pembiayaan mudharabah terhadap pendapatan bagi hasil PT Bank Syariah Mandiri Tahun 2016-2017. Penelitian ini bertujuan untuk menegetahui Pembiayaan Mudhrabah terhadap Pendapatan Bagi Hasil Bank Syariah Mandiri Tahun 2013-2017.

Penelitian ini menggunakan jenis penelitian Kuantitatif yang bersifat deskriptif. Dengan menggunakan data sekunder PT Bank Syariah Mandiri yang tersedia pada website dengan sampel laporan keuangan tahun 2013-2017 secara triwulan berupa laopran neraca dan laba rugi, metode data yang digunakan adalah menggunakan analisis deskriptif yang dilakukan peneliti adalah cara perhitungan pembiayaan bagi hasil mudharabah dan melakukan perbandingan Pembiayaan Mudharbah dan Pendapatan Bagi Hasil pada PT Bank Syariah Mandiri pada periode 2013-2017.

Hasil penelitian ini menunjukan bahwa pada PT Bank Syariah Mandiri yang penulis analisis mengalami terjadinya stabilitas pada Pembiayaan mudharabah dan pendpatan bagi hasil pada tahun 2013 ,2014 , dan 2015 pada Pembiayaan Mudharabah, sedangkan pada Pendapatan Bagi hasil terjadi kestabilsan pada tahun 2013, 2014, 2015 dan 2016. dan analisis ini juga terjadinya penurunan yang terjadi pada PT Bank Syariah Mandiri dari Pembiayaan Mudharabah terjadi penurunan pada tahun 2016 dan 2017 dikarenakan terjadinya kelalaian atau kesalahan dalam pengelola dana tersebut. sedangkan pada pendapatan bagi hasil terjadi penurunan pada tahun 2017. Dari hasil analisis tersebut bahwa pembiayaan Mudharabah terhadap pendapatan bagi hasil tidak signifikan antara Pembiayaan Mudhrarbah dan Pendpatan Bagi hasil PT Bank Syariah Mandiri tidak seimbang antara Pembiayaan Mudharabah dan Pendapatan Bagi hasil lebih besar pembiayaan dari pada pendapatan bagi hasil yang diperoleh oleh PT Bank Syariah Mandiri dari tahun 2013-2017.

Kata Kunci: Pembiayaan Mudharabah, Pendapatan. 


\section{PENDAHULUAN}

Ekonomi Islam telah diajarkan oleh dan dipraktekkan Rasulullah SAW sebagai pembawa risalah Islam. Ilmu ekonomi merupakan ilmu yang mempelajari perilaku individu dan masyarakat untuk membuat pilihan dengan uang atau tanpa uang menggunakan sumber-sumber terbatas.

Dengan cara alternatif terbaik untuk menghasilkan barang dan jasa sebagai pemuas kebutuhan manusia yang relatif tidak terbatas.

Keuangan Islam bertujuan mendorong pertumbuhan ekonomi rakyat, menjaga kesatuan juga keseimbangan sektor rill dan sektor moneter. Namun juga harus memperhatikan dasar hukum Islam yaitu agar terhindar dari ketidakadilan dengan semakin berkembangnya aktivitas perekonomian masyarakat.

Maka mereka memerlukan institusi yang bertugas untuk mengelola uang yang mereka miliki. Lembaga keuangan yaitu merupakan perusahaan yang bergerak dibidang keuangan. Dan lembaga keuangan bertugas menghimpun dana, menyalurkan dana atau kedua-duanya.

Perbankan Syariah memiliki fungsi yaitu menghimpun dana, penyaluran dana, dan menyediakan jasa-jasa sesuai prinsip Islam. Dimana penyaluran dana pada Bank yaitu adanya pembiayaan dalam beberapa produk salah satunya produk pembiayaan Mudharabah. Model pembiayaan Bank Syariah lebih diarahkan pada pembiayaan dengan prinsip bagi hasil yang menekan pola hubungan kemitraan antara Bank dan nasabah.

Terdapat 4 Bank Syariah yang memiliki aset terbesar di Indonesia, yaitu Bank Syariah Mandiri, Bank Muamalat Indonesia, Bank Rakyat Indonesia Syariah, dan Bank Negara Indonesia Syariah. Bank Syariah Mandiri memegang urutan pertama pemegang aset terbesar di Indonesia dari keempat Bank Syariah terbesar di Indonesia.

Kehadiran BSM (Bank Syariah Mandiri) sejak tahun 1999, sesungguhnya merupakan hikmah sekaligus berkah pasca krisis ekonomi dan moneter 1997-1998. Sebagaimana diketahui, krisis ekonomi dan moneter sejak Juli 1997, yang disusun dengan krisis multi-dimensi termasuk dipanggung politik nasional, telah menimbulkan beragam dampak negatif yang sangat hebat terhadap seluruh sendi kehidupan masyarakat, tidak terkecuali di dunia usaha. Dalam kondisi tersebut, industri perbankan nasional yang didominasi oleh bank-bank konvensional mengalami krsis luar biasa. 
Pemerintah akhirnya mengambil tindakan dengan merestrukturisasi dan merekapitalisasi sebagian bank-bank indonesia. Pada saat bersamaan, pemerintah melakukan penggabungan (Merger) empat Bank (Bank Dagang Negara, Bank Bumi Daya, Bank Exim, dan Bap Indo) menjadi satu Bank baru bernama PT. Bank Mandiri (Persero) pada tanggal 31 Juli 1999. Kebijakan penggabungan tersebut juga menempatkan dan menetapkan PT. Bank Mandiri (Persero) Tbk. Sebagai pemilik mayoritas baru BSB.

Sebagai tindak lanjut dari keputusan merger, Bank Mandiri melakukan konsolidasi serta membentuk tim pengembangan perbankan Syariah. Pembentukan tim ini bertujuan untuk mengembangkan layanan perbankan Syariah dikelompok perusahaan Bank Mandiri, sebagai respon atas diberlakunya UU No. 10 tahun 1998, yang memberi peluang bank umum untuk melayani transaksi Syariah (dual banking system).

Tim pengembangan perbankan Syariah memandang bahwa pemberlakuan UU tersebut merupakan momentum yang tepat untuk melakukan konversi PT Bank Susila Bakti dari Bank Konvensional menjadi Bank Syariah. Oleh karenanya, tim pengembangan perbankan Syariah segera mempersiapkan system dan infrastrukturnya, sehingga kegiatan BSB berubah dari bank konvensional menjadi bank yang beroperasi berdasarkan prinsip Syariah dengan nama PT Bank Syariah Mandiri sebagaimana tercantum dalam akta notaris: Sutjipto,SH, No. 23 tanggal 8 September 1999. Perbuahan kegiatan BSB menjadi Bank Umum Syariah dikukuhkan oleh Gubernur Bank Indonesia melalui SK Gubernur BI No. 1/24/KEP.Bl/1999, 25 Oktober 1999.

Melalui Surat Keputusan Deputi Gubernur Senior Bank Indonesia No. 1/1/KEP.DGS/1999, Bl menyetujui perubahan nama menjadi PT Bank Syariah Mandiri. Menyusul pengukuhan dan pengakuan legal tersebut, PT Bank Syariah Mandiri secara resmi mulai beroperasi sejak Senin tanggal 25 Rajab 1420H atau tanggal 1 November 1999. PT Bank Syariah Mandiri hadir, tampil dan tumbuh sebagai Bank yang mampu memandukan idealisme usaha dengan nilai-nilai rohani, yang melandasi kegiatan operasionalnya.

Pada bank Syariah memiliki sejumlah produk pembiayaan salah satunya yaitu pembiayaan Mudharabah merupakan bentuk kerja sama antara dua atau lebih pihak. Dimana pemilik modal (Shahibul Al-Mal) mempercayakan sejumlah modal kepada pengelola (mudharib) dengan suatu 
perjanjian pembagian keuntungan. Kerja sama dalam paduan kontribusi $100 \%$ modal kas dari Shahibul Al-mal. Pembiayaan Mudharabah merupakan pembiayaan yang sedikit lebih rumit, karena beresiko tinggi dan membutuhkan sikap jujur dan saling percaya antara Shahibul Maal dengan Mudhrib.

Perjanjian Mudharabah dapat juga dilakukan antara beberapa penyedia dana dan pelaku usaha. Jika usaha mengalami kerugian, maka seluruh kerugian ditanggung oleh pemilik dana, kecuali jika ditemukan adanya kelalaian atau kesalahan oleh pengelola dana, seperti penyelewangan, kecurangan, dan penyalahgunaan dana. Keuntungan usaha secara Mudharabah dibagi menurut kesepakatan yang dituangkan dalam kontrak, sedangkan apabila rugi ditanggung oleh pemilik modal selama kerugian itu bukan akibat kelalaian si pengelola.

Masyarakat awam mengetahui bahwa bank Syariah lebih diarahkan pada pembiayaan dengan prinsip bagi hasil yaitu pembiayaan Mudharabah. tetapi kenyataanya bank lebih memilih menyaurkan pembiayaan Mudharabah. Akan tetapi dilihat dari tingkat pengaruh pembiayaan Mudharabah terhadap pendapatan bank apakah pembiayaan Mudharabah berpengaruh signifikan terhadap pendapatan bank.

Dilihat dari kategori pembiayaan pada Bank, pembiayaan Mudharabah merupukan pembiayaan terendah diantara pembiayaan lainya. Resiko tinggi yang dihadapi oleh Bank dikarenakan adanya masalah ketidakpastian pendapatan keuntungan. Sehingga ada kecenderungan bank kurang berminat menyalurkan pembiayaan Mudharabah.

Menurut Ulama Fiqih kerjasama "Mudharabah" sering juga disebut dengan "Qiradh". Dalam fiqhus sunnah juga disebutkan bahwa Mudharabah bisa dinamakan denagan qiradh yang artinya memotong. Karena pemilik modal memotong sebagian hartanya agar di perdagangkan dengan memperoleh sebagian keuntungan.

Pembiayaan Mudharabah juga sebagai bentuk penolakan terhadap sistem bunga yang diterapkan oleh bank konvesional dalam mencari keuntungan. Pelarangan bunga ditinjau dari ajaran islam merupakan perbuatan riba yang diharamkan di dalam Al-Qur'an. sebab larangan riba tersebut bukanlah meringankan beban orang yang membutuhkan bantuan didalam hal ini merupakan anggota, melainkan merupakan tindakan memperalat dan memakan harta orang lain. 
Tabel 1.l. Perkembangan Pendpatan pada Pembiayaan Mudharabah Pada PT Bank Syariah Mandiri Tahun 2013-2017 (Dalam Jutaan Rupiah)

\begin{tabular}{|c|c|c|}
\hline TAHLN & $\begin{array}{c}\text { PEMALYYAN } \\
\text { MUDHARABAH }\end{array}$ & $\begin{array}{c}\text { PEDAPATANBAOI HASIL. } \\
\text { MUDHAR_ABAH }\end{array}$ \\
\hline 2013 & 41.625 .477 & 549.293 \\
\hline 2014 & 40.706 .607 & 427.909 \\
\hline 2015 & 11.556 .279 & 364.436 \\
\hline 2016 & 12.853 .013 & 362.083 \\
\hline 2017 & 13.552 .548 & 367.275 \\
\hline
\end{tabular}

Sumber : Laporan Keuangan PT Bank Syariah Mandiri Tahun 2013-2017

Besar kecilnya pembiayaan dapat mempengaruhi jumlah pendapatan yang diterima oleh bank. Ketika pembayar lancar maka dapat meningkatkan pendapatan bagi pihak bank yang dapat mendorong kinerja dalam pebankan. jika pembiayaan mudharabah yang diberikan tinggi maka pendapatan bagi hasil yang diterima naik atau tinggi, sedangkan tujuan dan manfaat pembiayaan mudharabah bagi nasabah yaitu memenuhi kebutuhan modal usaha melalui sistem kemitraan dengan lembaga keuangan syariah.

Pada kegiatan perbankan syariah adanya pendapatan untuk melihat suatu keadaan bank ataupun suatu perusahaan, oleh sebab itu bank berusaha untuk semaksimalkan mungkin untuk mendapatkan pendapatan yang diharapkan. Menurut PSAK No.23 menyatakan bahwa pendapatan diukur dengan nilai wajar imbalan yang diterima atau yang dapat diterima. Pada bank syariah adanya sumber pendapatan bank yaitu pembiayaan bagi hasil, pembiayaan jual beli, ijarah, dan jasa perbankan.

Potensi untuk berkembang lebih maju di masa mendatang masih sangat besar, namun masih ada banyak kendala dan tantangan dalam operasional Bank Syariah Mandiri. Kualitas pembiayaan sangat berpengaruh terhadap efektifitas pendapatan yang yang di harapkan. Oleh karena itu kualitas ini harus dijaga jangan sampai menjadi pembiayaan bermasalah, yang akibatnya bukan saja menyebabkan kerugian karena tidak terbayarnya kembali dana yang ditanamkan dalam pembiayaan tersebut.

\section{METODE PENELITIAN}

\section{Deskripsi Objek Penelitiann}

Nilai-nilai perusahaan yang menjunjung tinggi kemanusiaan dan integritas telah tertanam kuat pada segenap insan Bank Syariah Mandiri (BSM) sejak awal pendirianya. Kehadiran BSM sejak tahun 1999, sesungguhnya merupakan hikmah sekaligus berkah pasca krisis ekonomi dan moneter 1997-1998, sebagaimana diketahui krisis ekonomi dan moneter sejak juli 1997, yang diusul dengan krisis multi-dimensi termasuk dipanggung politik nasional, telah menimbulkan beragam dampak negatif yamg sangat 
hebat tehadap seluruh sendi kehidupan dimasyarakat tidak tekecuali dunia usaha.

Dalam kondisi tersebut, industri perbankan nasional yang didominasi oleh bank-bank konvensional mengalami krisis luar biasa. Pemerintah akhirnya mengambil tindakan dengan merestrukturisasi dan merekapitalisasi sebagian bank bank Indonesia. Pada saat bersamaan, pemerintah melakukan penggabungan (Merger) empat bank (Bank Dagang Negara, Bank Bumi Daya, Bank Exim, dan Bapindo) menjadi satu bank baru bernama PT Bank Mandiri (Persero) pada tanggal 31 Juli 1999, kebijakan penggabungan tersebut juga menempatkan dan menetapkan PT Bank Mandiri (Persero) Tbk sebagai pemilik mayoritas baru BSB.

Sebagai tindak lanjut dari keputusan merger, Bank Mandiri melakukan konsolidasi serta membentuk tim pengembanggan perbankan syariah. Pembentukan tim ini bertujuan untuk mengembangkan layanan perbankan syariah di kelompok perusahan Bank Mandiri, sebagai respon atas berlakunya UU No.10 Tahun 1998, yang memberi peluang bank umum untuk melayani transaksi syariah (dual banking system). Tim pengembanggan perbankan syariah memandang bahwa pemberlakuan UU tersebut merupakan momentum yang tepat untuk melakukan konversi PT

Bank Susila Bakti dari bank konvensional menjadi bank syariah.

Oleh karenanya, tim pengembanggan perbankan syariah segera mempersiapkan sistem dan infrastrukturnya, sehingga kegiatan usaha BSB berubah dari bank konvensional menjadi bank yang beroperasi berdasarkan prinsip syariah dengan nama PT. Bank Syariah Mandiri sebagaimana tercantum dalam akta notaris : Sutjipto, SH, No.23 Tanggal 8 September 1999. Perubahan kegiatan usaha BSB menjadi bank umum syariah dilakukan oleh gubernur Bank Indonesia melalui SK Gurbenur Bl No. 1/24/KEP.Bl/1999, 25 Oktober 1999. Selanjutnya, melalui surat keputusan Deputi Gubernur senior Bank Indonesia No. 1/1/KEP.DGS/1999, Bl menyetujui perubahan nama menjadi PT Bank Syariah Mandiri.

Menyusul pengukuhan dan pengakuan legal tersebut, PT Bank Syariah Mandiri secara resmi mulai beroperasi sejak Senin tanggal 25 Rajab $1420 \mathrm{H}$ atau tanggal 1 Nopember 1999. PT Bank Syariah Mandiri hadir, tampil dan tumbuh sebagai bank yang mampu memadukan idealisme usaha dengan nilai-nilai rohani, yang melandasi kegiatan operasionalnya. Harmoni antara idealisme usaha dan nilai-nilai 
rohani inilah yang menjadi salah satu keunggulan Bank Syariah Mandiri dalam kiprahnya di perbankan Indonesia, BSM hadir untuk bersama membangun Indonesia menuju Indonesia yang lebih baik.

\section{Populasi \& Sampel}

\section{Populasi}

Populasi adalah wilayah generalisasi yang terdiri atas subyek atau obyek dengan kualitas dan karakteristik tertentu yang ditetapkan oleh peneliti untuk dipelajari dan kemudian ditarik kesimpulan. Sedangkan sampel adalah bagian dari polusi yang diharapkan dapat mewakili populasi penelitian. Populasi dalam penelitian ini adalah seluruh laporan keuangan Bank Syariah Mandiri.

\section{Sampel}

Sampel adalah laporan keuangan triwulan Bank Syariah Mandiri selama 5 tahun pada periode 2013-2017. Dengan menggunakan metode purposive sampling yaitu teknik penentuan sampel dengan pertimbangan atau kriteriakriteria tertentu. Pada penelitian ini menggunakan data laporan keuangan triwulan selama 5 tahun merupakan data yang sesuai dengan kebutuhan peneliti untuk mencari pendapatan perusahaan tersebut, dan tahun 20132017 adalah tahun dimana laporan keuangan telah dipublikasikan secara lengkap.

\section{Metode Pengambilan Data}

Data adalah aspek penting dalam sebuah penelitian. Data tersebut nantinya akan diolah untuk mengetahui kebenaran dalam penelitian. Metode pengumpulan data yang dilakukan peneliti adalah dokumentasi yaitu dengan menganalisi dokumen-dokumen berupa laporan keuangan perbulan publikasi yang diperoleh melalui website resmi dan dokumen yang didapat dari literatur penelitian seperti buku dan referensi lainnya. Metode pengumpulan data menggunakan :

\section{Observasi}

Tinjauan dalam penelitian studi tokoh dilakukan dengan membuat deskripsi tentang bahan yang dihasilkan oleh peneliti sebelumnya, bisa dalam bentuk laporan, artikel, jurnal laporan keuangan yang dapat melalui website. Penjelajah data kepustakaan ini hendaknya dilakukan seluas mungkin hingga dapat pastikan bahwa penelitian yang akan dilakukan benar relevan dan penting.

\section{Metode Dokumentasi}

Metode dokumentasi yaitu mencari data mengenai hal-hal atau variabel yang berupa catatan, transkip buku, laporan keuangan, dan sebagiannya dalam menggunakan metode 
dokumentasi mencatat hal-hal yang bersifat bebas atau belum ditentukan dalam daftar variabel peneliti dapat menggunakan kalimat bebas.

\section{Metode Analisis Data}

Dalam penelitian ini penulis menggunakan metode kualitatif dengan menggunakan analisis deskriptif. Metode kualitatif adalah metode penelitian berlandaskan pada filsafat postpositivisme, digunakan untuk meneliti pada kondisi obyek yang alamiah (sebagai lawannya eksperimen) hasil penelitian kualitatif lebih menekankan dari pada generlaisasi (Sugiyono, 2012:14). Analisis pada tahap penelitian ini sebagai berikut :

1. Analisis domain

Pada tahap ini penulis berupaya untuk memperoleh gambaran umum dan menyeluruh dari data yang telah diambil pada laporan keuangan PT Bank Syariah Mandiri yang telah dipublikasi untuk menjawab fokus penelitian.

2. Analisis Taksonomi

Pada tahap ini penulis berupaya menjabarkan data Pembiayaan Mudharabah dan Pendapatan mudharabah dari laporan keuangan menjadi lebih rinci dengan melakukan obervasi.

3. Analisis Komponensial
Pada tahap ini penulis berupaya untuk memahami dengan cara mencari perbedaan yang spesifik setiap rincian yang ada pada data Pembiayaan Mudharabah dan Pendapatan Mudharabah dari laporan keuangan yang diperoleh.

\section{PEMBAHASAN}

\section{Analisis data Pembiayaan Mudharabah}

Data- data yang digunakan dalam analisis ini diperoleh dari Laporan Keuangan Triwulan PT Bank Syariah Mandiri. Berikut penulis akan menyajikan data Pembiayaan Mudharabah selama Lima tahun terakhir dari tahun 2013 sampai dengan 2017

\section{Tabel 4.1}

Pembiayaan Mudharabah PT Bank Syariah Mandiri Periode 2013-2017 ( Dalam Rupiah )

\begin{tabular}{|c|c|c|c|c|c|}
\hline \multirow{2}{*}{ Eulan } & \multicolumn{5}{|c|}{ Tintum } \\
\hline & 211) & 2014 & 2019 & 2016 & 2017 \\
\hline Mush & 9.921366 & $10 \times 66154$ & 2158566 & $3,75.12$ & 2055212 \\
\hline Sin & 10.452317 & $10 \times 6158$ & 2311365 & 1597104 & 150339 \\
\hline Sept & 10.503325 & 30.194 .18 & 283566 & 3.3496 & 39317 \\
\hline Dochber & to.715035 & 9111.15 & 2311566 & 2191301 & 39489 \\
\hline Totil & 41.5497 & $40.766 .60 ?$ & 1154627 & 120013 & 13.55254 \\
\hline
\end{tabular}

Sumber : Laporan Keuangan PT Bank Syariah Mandiri periode 2013-2015

Berdasarkan data tabel diatas Pembiayaan Mudharabah terjadi peningkatan dan penurunan pada data laporan keuangan triwulan PT Bank Syariah Mandiri yang dianalisis sebagai berikut : 
1. Pada tahun 2013 dengan 2014 mengalami terjadi adanya penurunan dengan selisih sebesar 918.870 .

2. Pada tahun 2014 dengan 2015 mengalami terjadi adanya penurunan dengan selisish sebesar 29.150.328.

3. Pada tahun 2015 dengan 2016 mengalami terjadi adanya peningkatan yaitu sebesar 1.296.734.

4. Pada tahun 2016 dengan 2017 mengalami terjadi adanya peningkatan yaitu sebesar 699.535.

\section{Pembiayaan Mudharabah} PT Bank Syariah Mandiri

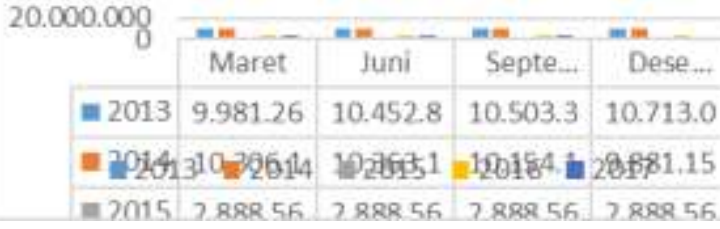

Gambar 4. 1

Pembiayaan Mudharabah PT Bank Syariah Mandiri

Analisis Perkembangan Pendapatan Bagi Hasil PT Bank Syariah Mandiri

Berikut penulis akan menyajikan data pendapatan PT Bank Syariah Mandiri selama Lima tahun terakhir dari tahun 2013 sampai dengan 2017.

Tabel 4.2

Pendapatan Bagi Hasil PT Bank Syariah Mandiri Periode 2013-2017

(Dalam Rupiah)
Sumber : Laporan Keuangan PT Bank Syariah Mandiri Periode 2013-2017.

Berdasarkan dari data tabel di atas Pendapatan Bagi Hasil terjadi peningkatan dan penurunan pada data laporan keuangan triwulan PT Bank Syariah Mandiri yang dianalisis sebagai berikut :

1. Pada tahun 2013 dengan 2014 mengalami terjadi adanya penurunan dengan selisih 215.972 .

2. Pada tahun 2014 dengan 2015 mengalami terjadi adanya penurunan dengan selisih 117.628 .

3. Pada tahun 2015 dengan 2016 mengalami terjadi adanya penurunan dengan selisih 48.173 .

4. Pada tahun 2016 dengan 2017 mengalami terjadi adanya peningkatan yaitu sebesar 19.144.

\begin{tabular}{|c|c|c|c|c|}
\hline \multicolumn{5}{|c|}{$\begin{array}{l}\text { Pendapatan Bagi Hasil } \\
\text { PT Bank Syariah Mandiri }\end{array}$} \\
\hline 1.000 .000 & Maret & Juni & Septe. & Dese \\
\hline$=2013$ & 113.802 & 267.180 & 406.845 & $543: 973$ \\
\hline$=2 \omega 201$ & 1315 gस14 & 2052010 & ISAM1400 & 2020.136 \\
\hline$-4 n+r$ & กา mอ & corran & anr ont & araner \\
\hline
\end{tabular}

Gambar 4. 2

Pendapatan Bagi Hasil PT Bank Syariah Mandiri

Perkembangan Pembiayaan Mudharabah Pada PT Bank Syariah Mandiri Periode 2013-2017.

\begin{tabular}{|l|c|c|c|c|c|}
\hline \multirow{2}{*}{ Bulan } & \multicolumn{5}{|c|}{ Tahuin } \\
\cline { 2 - 6 } & 2013 & 2014 & 2015 & 2016 & 2017 \\
\hline Matet & 113.802 & 115.981 & 90.228 & 84.971 & 80.539 \\
\hline Jumi & 267.180 & 235.310 & 186.643 & 168.463 & 176.567 \\
\hline Sept & 406.845 & 344.400 & 296.891 & 274.507 & 275.486 \\
\hline Desember & 543.973 & 420.136 & 364.436 & 362.083 & 367.275 \\
\hline Total & 1.333 .813 & 1.117 .841 & 940.213 & 892.040 & 911.184 \\
\hline
\end{tabular}


Tabel 1.3

Akumulasi Perubahan Pembiayaan Mudharabah PT Bank Syariah Mandiri Periode 2013-2017

\begin{tabular}{|c|c|c|c|}
\hline Taban & 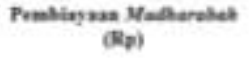 & $\begin{array}{l}\text { Rerobaha } \\
(\boldsymbol{D P})\end{array}$ & $\begin{array}{c}\text { Presentase } \\
(\infty)\end{array}$ \\
\hline 200 & $4 \mathrm{C}_{025} \mathrm{Ct}$ & - & - \\
\hline 2014 & 40.706 6007 & 918.57 & 2.258 \\
\hline 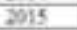 & 1155627 & 215035 & 2.25 \\
\hline 2015 & 2599013 & (1) 26750 & 70005 \\
\hline 2017 & 1552.48 & 1002535 & 3.65 \\
\hline Toed & 120.253 .044 & 2007231 & 20085 \\
\hline
\end{tabular}

Sumber : Laporan Keuangan Triwulan PT BSM Periode 2013-2017

Pada Tahun 2013 Total Pembiayaan Mudharabah sebesar 41.625.477,sedangkan pada Tahun 2014 total Pembiayaan Mudharabah sebesar 40.706.607,- hal ini menunjukkan bahwa pembiayaan Mudharabah mengalami kenaikaan sebesar 2,26\% dari tahun 2013 menuju tahun 2014. Kenaikan juga terjadi pada Tahun 2015 dengan total Pembiayaan Mudharabah sebesar 11.556.279,- dengan presentase sebesar $2.52 \%$. Dan adapun penurunan yang terjadi pada pembiayaan tersebut pada tahun 2016 dengan total Pembiayaan Mudharabah sebesar 12.853.013 dengan presentase sebesar 10.09\%. dan pada akhir Tahun juga terjadi penurunan yang terjadi pada tahun 2017 dengan total Pembiayaan Mudharabah sebesar 13.552.548,dengan presentase sebesar $5.16 \%$.

Dengan ini penulis dapat menyimpulkan bahwa Pembiayaan Mudharabah dari Tahun 2013 sampai dengan 2017 mengalami Kenaikan dan
Penurunan sebesar 28.072.911,- dengan perolehan presentase sebesar $20.03 \%$. dan Pembiayaan ini terjadi penurunan nilai akibat hilang, rusak atau faktor lain sebelum dimulainya usaha karena adanya kerusakan atau sebab lainya tanpa adanya kelalaian atau kesalahan pihak pengelola dana, maka rugi tersebut mengurangi saldo Pembiayaan Mudharabah dan diakui sebagai Kerugian Bank.

\section{Perkembangan Pendapatan Bagi Hasil} Pada PT Bank SYariah Mandiri Periode $2013-2017$

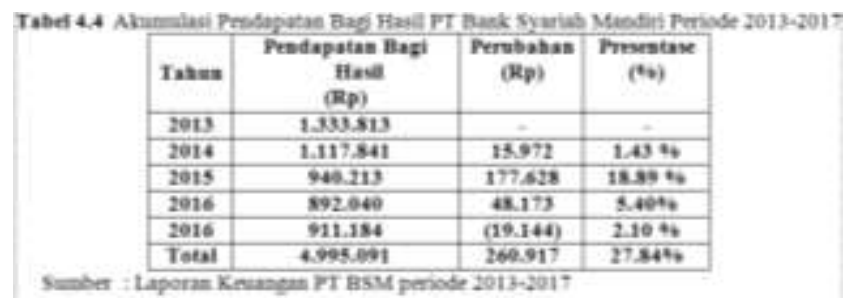

Pada Tahun 2013 total Pendapatan Bagi Hasil PT Bank Syariah Mandiri sebesar 1.133.813,- sedangkan pada Tahun 2014 total Pendapatan Bagi Hasil Mudharabah PT Bank Syariah Mandiri sebesar 1.117.841,- . Hal ini menunjukkan bahwa Pendapatan Bagi Hasil PT Bank Syariah Mandiri mengalami kenaikan sebesar $1.43 \%$ dari tahun 2013 menuju tahun 2014. Kenaikan juga terjadi pada Tahun 2015 dengan total Pendapatan Bagi Hasil Mudharabah pada PT Bank Syariah Mandiri sebesar 940.213,dengan perolehan Presentase sebesar 18.89\%. Dan pada Tahun 2016 juga 
mengalami kenaikan Pendapatan Bagi Hasil PT Bank Syariah Mandiri dengan total 892.040,- dengtan perolehan presentase sebesar 5,40\%. Pada Tahun akhir mengalami Penurunan pada pendapatan Bagi Hasil PT Bank Syariah Mandiri dengan total 911.091,- dengan perolehan presentase sebesar $2.10 \%$.

Dengan ini penulis dapat menyimpulkan bahwa Pendapatan Bagi Hasil pada PT Bank Syariah Mandiri Dari tahun 2013-2017 mengalami Kenaikan dan Penurunan sebesar 260.917,-- dengan perolehan presentase sebesar $27.84 \%$

Perkembangan Pembiayaan Mudharabah Terhadap Pendapatan Bagi Hasil Pada Bank Syariah Mandiri Periode 2013-2017.

Berdasarkan dari hasil penelitian di atas pada Pembiayaan Mudharabah dan Pendapatan adanya terjadi fluktuasi pada periode 2013-2019 yang akan dijabarkan sebagai berikut :

\section{Tabel 4.5}

Pembiayaan Mudharabah terhadap pendapatan bagi hasil PT Bank Syariah Mandiri periode 2013-2017

(Dalam Presentase)
\begin{tabular}{|l|l|l|l|l|l|}
\hline Triwlan & 2013 & 2014 & 2015 & 2016 & 2017 \\
\hline Vard & $87.70 \%$ & $88.86 \%$ & $32.01 \%$ & $44.19 \%$ & $34.12 \%$ \\
\hline Juni & $39.12 \%$ & $44.04 \%$ & $15.48 \%$ & $21.32 \%$ & $19.31 \%$ \\
\hline September & $25.82 \%$ & $29.48 \%$ & $97.29 \%$ & $12.19 \%$ & $13.04 \%$ \\
\hline Desember & $16.69 \%$ & $23.52 \%$ & $79.26 \%$ & $8.70 \%$ & $9.25 \%$ \\
\hline
\end{tabular}

$$
\text { Pada tabel Pembiayaan }
$$

Mudharabah dan Pendapatan Bagi Hasil

PT Bank Syariah Mandiri diatas maka dapat diketahui bahwa analisis secara perbulan sebagai berikut yaitu :

1. Pada bulan Maret 2014 merupakan jumlah tertinggi dari pembiayaan Mudharabah dan pendapatan bagi hasil yang diangguhkan oleh PT Bank Syariah Mandiri yaitu sebesar $88.86 \%$ serta pada tahun 2015 merupakan angka terendah yaitu sebesar $32.01 \%$.

2. Pada bulan Juni 2014 merupakan jumlah tertinggi dari Pembiayaan Mudharabah dan Pendapatan Bagi hasil yang diangguhkam oleh PT Bank Syariah Mandiri yaitu sebesar $44.04 \%$ serta pada tahun 2015 merupakan angka terendah yaitu sebesar $15.48 \%$.

3. Pada bulan September 2015 merupakan jumlah tertinggi dari Pembiayaan Mudharabah dan Pendapatan Bagi Hasil yang diangguhkan oleh PT Bank Syariah Mandiri yaitu sebesar $97.29 \%$ serta pada tahun 2016 merupakan angka terendah yaitu sebesar $12.19 \%$.

4. Pada bulan Desember 2015 merupakan jumlah tertinggi dari Pembiayaan Mudharabah dan Pendapatan Bagi Hasil yang diangguhkan oleh PT Bank Syariah Mandiri yaitu sebesar $79.26 \%$, serta pada tahun 2016 merupakan angka terendah yaitu sebesar $8.70 \%$. 
Berdasarkan daftar tabel Pembiayaan Mudharabah dan Pendapatan Bagi Hasil PT Bank Syariah Mandiri diatas maka dapat di ketahui bahwa analisis secara pertahun yaitu:

l. Pada tahun 2013 dibulan Maret merupakan jumlah tertinggi dari Pembiayaan Mudharabah dan Pendapatan Bagi Hasil yang diangguhkan oleh PT Bank Syariah Mandiri yaitu sebesar $87.70 \%$, serta pada bulan Desember angka yang terendah yaitu sebesar $19.69 \%$.

2. Pada tahun 2014 dibulan Maret merupakan jumlah tertinggi dari Pembiayaan Mudharabah dan Pendapatan Bagi hasil yang diangguhkan oleh PT Bank Syariah Mandiri yaitu $88.86 \%$, serta pada bulan Desember angka yang terendah yaitu sebesar $23.52 \%$.

3. Pada tahun 2015 dibulan September merupakan jumlah tertinggi dari Pembiayaan Mudharabah dan Pendapatan Bagi Hasil yang diangguhkan oleh PT Bank Syariah Mandiri yaitu 97.29\%, serta pada bulan Juni angka yang terendah yaitu sebesar $15.48 \%$.

4. Pada tahun 2016 dibulan Maret merupakan jumlah tertinggi dari Pembiayaan Mudharabah dan Pendapatan Bagi Hasil yang diangguhkan oleh PT Bank Syariah
Mandiri yaitu $44.19 \%$, serta pada bulan Desember angka yang terendah yaitu sebesar $8.70 \%$.

5. Pada tahun 2017 dibulan Maret merupakan jumlah tertinggi dari Pembiayaan Mudharabah dan Pendapatan Bagi Hasil yang diangguhkan oleh PT Bank Syariah Mandiri yaitu $34.12 \%$, serta pada bulan Desember angka yang terendah yaitu sebesar $9.25 \%$.

\section{Pembiayaan Mudharabah Terhadap \\ Pendapatan Bagi Hasil...}

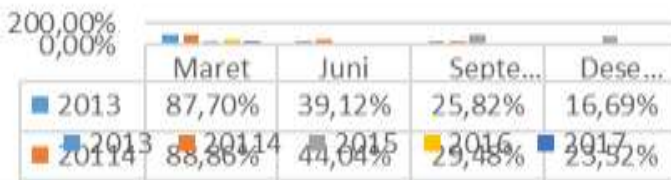

Gambar 4. 3 Pembiayaan Mudharabah Terhadap Pendapatan Bagi Hasil PT Bank Syariah Mandiri

2.1.1 Prosedure Pengajuan dan Pencairan Pembiayaan Mudharabah PT Bank Syariah Mandiri

PT Bank Syariah Mandiri memiliki prosedur yang harus dipatuhi oleh pegawawai maupun anggota. Sehingga dalam operasional Pembiayaan Mudharabah pada PT Bank Syariah Mandiri dapat berjalan dengan baik. Adapun prosedur Pembiayaan Mudharabah sebagai berikut :

1. Tahap Pengajuan 
Seeseorang yang mengajukan Pembiayaan maka dia harus memenuhi beberapa syarat, yaitu :

a. Sudah menjadi anggota minimal selama 3 bulan.

b. Mempunyai saldo minimal tabungan sebesar Rp. 750.000.

c. Tabungan yang digunakan merupakan milik pribadi.

2. Wawancara

Setelah memenuhi syarat diatas tersebut, selanjutnya anggota yang mengajukan Pembiayaan akan diwawancarai oleh seorang karyawan PT Bank Syariah Mandiri untuk dicatat dibuku daftar pinjaman yang akan diteruskan ke bendahara. Pertanyaan pada saat wawancara tersebut berisi keterangan tentang:

a. Tujuan Mengajukan Pembiayaan.

b. Jumlah pengajuan.

c. Kapan waktu dibutuhkannya.

3. Tahap analisa Pada tahap ini PT Bank Syariah Mandiri akan dapat mengetahui apakah anggota tersebut layak mendapatkan Pembiayaan Mudharabahatau tidak. Tahap ini juga berguna bagi PT Bank Syariah Mandiri untuk meminimalkan risiko dari penyaluran pembiayaan kepada anggota. Adapun yang dilakukan pada tahap ini adalah : a. Melakukan analisa pada nasabah dengan menggunakan aspek $5 \mathrm{C}$ yaitu

\section{1.) Character}

Analisa Character berguna untuk mengetahui watak dan sifat anggota. Analisa ini dilakukan untuk memastikan bahwa anggota tidak memiliki sifat buruk, bukan penipu dan memiliki reputasi buruk di masyarakat.

\section{2.) Capacity}

Analisa Capacity adalah analisa yang bertujuan untuk mengetahui kemampuan anggota untuk membayar angsuran dari pembiayaan. Analisa ini dapat dilakukan dengan melihat :

(a) Laporan keuangan calon nasabah (Pendpatan dan Pengeluaran).

(b) Banyaknya kewajiban yang ditanggung.

3.) Capital

Analisa yang bertujuan melihat kekayaan calon nasabah hal ini dilakukan sebagai penguat bahwa calon nasabah tidak mengandalkan dana pembiayaan tapi masih memiliki kekayaan lain yang digunakan untuk memenuhi kebutuhan. Kekayaan nasabah yang dimaksud berupa asset tanah dan bangunan, tempat usaha, barang 
berharga (Mobil, Sepeda Motor) dan peralatan kerja.

\section{4.) Collateral}

Analisa Collateral adalah analisa yang digunakan untuk melihat nilai jaminan. Nilai jaminan minimal $70 \%$ dari jumlah Pembiayaan. Jaminan ini berguna untuk backup jika dalam perjalanan angsuran nasabah tidak bisa memenuhi kewajibannya.

\section{5.) Condition}

Analisa bertujuan untuk melihat kondisi perekonomian calon nasabah. Untuk melihat apakah usaha calon nasabah masih bisa terus berkembang atau justru atau mengalami penurunan.

b. Mengitungkewajaran besarnya pembiayaan.

c. Melakukan analisa resiko.

d. Membuat kesimpulan dan menetapkan persyaratan pembiayaan. Apabiladisetujui, maka anggota akan segera diberi tahu dan diberikan penjelasan mengenai aturan pembayaran angsuran, yaitu :

1. Selama mempunyai angsuran, maka batas saldo minimum tabungan dibekukan atau tidak dapat diambil sampai angsuran tersebut terlunasi.

2. Untuk pembiayaan yang besarnya Rp. 3.000.0000 keatas memberikan sesuatu yang dapat dijadikan sebagai jaminan.

3. Membayar sejumlah biaya yang terdiri dari biaya administrasi dan materai. Sebenarnya biaya tersebut adalah sebuah kewajiban yang harus dibayarkan oleh anggota kepada PT Bank Syariah Mandiri diluar dari jumlah, akan tetapi pada umumnya anggota lebih memilih untuk membayar biaya tersebut diambil (dipotong) dari jumlah pembiayaan, mengurangi nominal uang yang diterima. Materai yang digunakan adalah materai 6.000 dan biaya administrasi berbeda-beda tergantung besarnya jumlah pembiayaan.

4. Tanggal jatuh tempo angsuran setiap bulan adalah sama dengan tanggal diterimannya pembiayaan dibulan berikutnya.

e. Penentuan Bagi Hasil Pembiayaan Mudharabah

Di lembaga keuangan syariah yaitu PT Bank Syariah Mandiri juga menerapkan metode perhitungan nisbah, akan Tetapi terdapat perbedaan dengan metode penghitungan nisbah pada hukum ekonomi syariah. Dasar yang dijadikan sebagai sumber rujukan adalah dari Departemen Koperasi (Depkop). 
Dalam penghitungan nisbah, jumlah nisbah yang dipakai adalah $1.5 \%$ perbulan untuk pembiayaan dan diambil dari kesepakatan kedua belah pihak.

Berikut metode perhitungan nisbah bagi hasil Pembiayaan Mudharabah menurut PT Bank Syariah Mandiri.

\section{Hasil Penelitian Metode Perhitungan Nisbah Bagi Hasil Pembiayaan Mudharabah PT Bank Syariah Mandiri dalam Prospektif Hukum Ekonomi Syariah.}

1. Pembiayaan Mudhrabah dalam hukum ekonomi syariah adalah pemberian modal usaha dalam hal kerja sama dimana salah satu pihak sumber dana (Shahibul Mal) dan salah seorang sebagai pengelola (Mudharib). Sedangkan dalam perhitungan bagi hasil atas dana yang dikelola pihak kedua dihitung dari hasil keuntungannya yang didapatkan perbulannya. Apabila pengelola mengalami kerugian tanpa adanya hal yang disengaja maka kerugian tersebut akan ditanggung bersama atau ditanggungpihak pemilik dana jika dilihat dari ketentuan kesepakatan bersama. Adapun ketentuan umum skema pembiayaan Mudharabah adalah sebagai berikut :

1. Jumlah modal yang diserahkan kepada nasabah selaku pengelola modal harus diserahkan tunai dan dapat berupa uang atau barang yang dinyatakan nilainya dalam satuan uang.

2. Apabila modal diserahkan secara bertahap, harus jelas tahapannya dan disepakati bersama.

3. Hasil dari pengelolaan modal Pembiayan Mudhrabah dapat diperhitungkan dengan cara, yakni : perhitungan dari pendapatan proyek (revenue sharing). Perhitungan dari keuntungan proyek (profit sharing) hasil usaha dibagi sesuai dengan persetujuan dalam akad.

Kalau ditinjau dari Hukum Ekonomi Syariah tentang nisbah bagi hasil Pembiayaan di PT Bank Syariah Mandiri memang sesuai dengan akad yang telah ditentukan dalam ketentuan hukum yang ada. Akan tetapi pada kenyataan diluar teori yang ada, bahwa nisbah bagi hasilnya terkadang mengikuti sistem ekonomi konvensional. Oleh karena itu upaya manajemen dana dan PT Bank Syariah Mandiri perlu dilakukan secara baik. Hal tersebut harus dilakukan untuk mencapai hasil keuntungan yang besar, agar bagi hasil yang dilakukan dapat meningkatkan tabungan nasabah.

Mudharabah adalah kerjasama antara pemilik dana atau penanaman modal dengan pengelola dana untuk melakukan usaha tertentu dengan 
pembagian keuntungan berdasarkan nisbah. Pada pembiayaan ini PT Bank Syariah Mandiri bertindak sebagai penyalur dana (Shahibul Maa) dan anggota atau nasabah sebagai penerima (Mudharib) untuk usaha dengan bagi hasil keuntungan yang telah ditentukan dengan Akad Syirkah atau kerja sama antara PT Bank Syariah Mandiri dengan anggota yang menjalankan usaha dengan modal seluruhnya dari PT Bank Syariah Mandiri. Dalam jangka waktu tertentu hasil keuntungan usahanya akan dibagi sesuai dengan kesepakatan, misalnya $20 \%$ untuk pemilik modal (PT Bank Syariah Mandiri) dan $80 \%$ untuk nasabah.

Karena dalam ketentuan lembaga keuangan syariah yang diutamakan demi kemaslahatan dan kesejahteraan umat. Dengan cara lembaga yang dikelola termasuk dalam prosedur pengelolaan yang baik dan tidak merugikan anggotanya walaupun hanya sedikit kemungkinan itu terjadi.

Berikut ini konsep bagi hasil antara PT Bank Syariah Mandiri dengan konsep bagi dalam ekonomi Syariah.

Tabel 4.5 Konsep Bagi Hasil Antara PT BSM dengan Konsep Bagi Hasil dalam Ekonomi Syariah

\begin{tabular}{|l|l|}
\hline $\begin{array}{l}\text { PT Bank Syariah } \\
\text { Mandiri }\end{array}$ & Ekonomi Syariah \\
\hline Nisbah ditentukan & Nisbah ditentukan \\
\hline
\end{tabular}

\begin{tabular}{|c|c|}
\hline $\begin{array}{l}\text { atas dasar } \\
\text { kesepakatan }\end{array}$ & $\begin{array}{ll}\text { atas } & \text { dasar } \\
\text { kesepakatan } & \end{array}$ \\
\hline $\begin{array}{l}\text { Nisbah dihitung } \\
\text { dari nominal } \\
\text { Pembiayaan }\end{array}$ & $\begin{array}{l}\text { Nisbah dihitung } \\
\text { dari pendapatan }\end{array}$ \\
\hline $\begin{array}{l}\text { Jangka waktu } \\
\text { pembiayaan } \\
\text { tergantung } \\
\text { kesepakatan }\end{array}$ & $\begin{array}{l}\text { Jangka waktu } \\
\text { pembiayaan } \\
\text { tergantung } \\
\text { kesepakatan }\end{array}$ \\
\hline
\end{tabular}

sebelumnya oleh Nurul Indriani dengan judul Analisis Bagi Hasil Pembiayaan Mudharabah Pada Koperasi Simpan Jaminan Wat Tamwil Al-Muqrin Pondok Cabe yang menyatakan bahwa Pencatatan dan perhitungan pembiayaan Mudharabah pada tugas akhir penulis mengalami penaikan pada pembiayaan tersebut. Hal tersebut sejalan dengan tugas akhir penulis dimana perhitungan pembiayaan Mudharabah memiliki metode perhitungan yang sama, yang dimana di PT Bank Syariah Mandiri mengalami penurunan pada akad perhitungan Pembiayaan Mudhrabah tahun 2013-2017.

\section{KESIMPULAN DAN SARAN}

\section{Kesimpulan}

Berdasarkan analisa dan pembahasan serta uraian-uraian sebelumnya mengenai pengaruh pembiayaan mudharabah terhadap pendapatan PT Bank Syariah Mandiri. Maka penulis 
dapat menarik kesimpulan sebagai berikut :

1. Dalam data Pembiayaan Mudharabah pada PT Bank Syariah Mandiri tahun 2013-2017 terjadi beberapa peningkatan dan penurunan dikarenakan terjadinya faktor yang mempengaruhi pembiayaan itu tersebut akibat rusak atau hilang, faktor lain juga terjadi karena sebelum dimulainya usaha adanya kerusakan atau sebab lainnya karena adanya kelalaian atau kesalahan pengelola dana, maka penurunan tersebut mengurangi saldo Pembiayaan Mudharabah dan terjadi penaikan Pembiayaan Mudharabah pada tahun 2014 dengan presentase 2.26\%, Tahun 2015 dengan presentase $2.52 \%$, dan penurunan juga terjadi pada tahun 2016 dengan presentase $10.09 \%$, dan pada tahun 2017 dengan presentase $5.16 \%$ jadi disimpulkan bahwa didalam Pembiayaan ini menyatakan setiap tahun terjadinya penaikan dan penurunan yang tidak pasti kapan akan terjadi penaikan dan penurunan.

2. Dalam data triwulan pendapatan pada PT Bank Syariah Mandiri Tahun 2013-2017, terjadi peningkatan dan penurunan yang terjadi selama tahun 2013-2017 dan peningkatan tersebut terjadi pada tahun 2014 dengan memperoleh presentase sebesar 1.43\%, pada tahun 2015 memperoleh presentase sebesar 18.89\%, pada tahun 2016 memperoleh presentase sebesar $5.40 \%$ sedangkan di tahun 2017 mengalami penurunan dengan memperoleh presentase sebesar $2.10 \%$ dalam pendapatan ini juga disimpulkan bahwa pada setiap tahun pendapatan tidak selamanya meningkat dan ada kalanya pendapatan juga mengalami penurunan.

Saran

Berdasarkan kesimpulan diatas maka penulis mencoba untuk memberikan beberapa saran yang mungkin bermanfaat bagi lembaga syariah tersebut diantaranya adalah :

I. PT Bank Syariah Mandiri harus bisa mempertahankan atau lebih baik lagi jika dapat meningkatkan kegiatan pemberian pembiayaan yang sudah dilaksanakan dengan baik agar dapat meningkatkan Pendapatan PT Bank Syariah Mandiri.

2. Usaha untuk memperluas pasar sasaran sebaiknya PT Bank Syariah Mandiri melakukan kegiatan promosi atau sosialisasi kepada masyarakat secara langsung maupun tidak langsung secara berkesinambungan 
baik melalui media massa maupun tokoh agama lebih meningkat lagi, untuk lebih memperkenalkan produk yang dihasilkan sesuai syariah kepada masyarakat luas, sehingga PT Bank Syariah Mandiri dapat menarik calon-calon anggotanya lebih luas.

\section{DAFTAR PUSTAKA}

------(2018, Desember 5). Diambil kembali dari Bank Syariah Mandiri:

www.syariahmandiri.co.id

-----(2018). Diambil kembali dari Laporan Tahunan Bank Syariah Mandiri:

www.syariahmandiri.co.id

Al Jaziri, A. R. (t.thn.). Kitabul Fiqh 'alal Madzahibil Arba'ah, Juz 3. Beirut: Darul Kutub Al 'llmiah.

badriyah. (2010). Metode Topsis. Student.EEpis-its.

Dwiartara, L. (t.thn.). Menyelam \& Menaklukan Samudera PHP. lsmail. (2011). Perbankan Syariah. Jakarta: Prenadamedia Group.

Kartiko, D. (2010). Sistem Pendukung Keputusan Pemberian Beasiswa di PT. Indomacro Prismatama Cabang Bandung.

Kusrini. (2010). Konsep dan Aplikasi Sistem Pendukung Keputusan. Yogyakarta: andi.
Kusumadewi, S., Hartati, S., Harjoko, A., \& Wardoyo, R. (2016). Fuzzy Multi-Attribute Decision Making (Fuzzy MADM) (Vol. 1). Yogyakarta: Graha llmu.

Muhamad. (2016). Sistem Bagi Hasil dan Pricing Bank Syariah. Yogyakarta: UIl Press Yogyakarta.

Muhammad. (2010). Manajemen Pembiayaan Mudharabah di Bank Syariah : Strategi Memaksimalkan Return dan Meminimalkan Risiko Pembiayaan di Bank Syariah sebagai Akibat Masalah Agency. Jakarta: PT Rajagrafindo Persada.

Mulia , N. G. (2014). Sistem Pendukung Keputusan Pemberian Bonus Tahunan Pada Karyawan Dengan Menggunakan Metode Simple Additive Weighting (SAW). Pelita Informatika Budi Darma,, 128-134. Munawar. (2005). Pemodelan Visual dengan UML. Yogyakarta: Andi.

Munawar. (2010). Pemodelan Visual dengan UML. Yogyakarta: Andi.

Purnamasari, 1. D., \& Suswinarno. (2011). Akad Syariah. Bandung: Kaifa.

Rivai, V., \& Arifin, A. (2010). Islamic Banking: Sebuah Teori, Konsep, dan Aplikasi. Jakarta: Sinar Grafika Offset.

Sauter, \& Vicki. (1997). Decision Support Systems: AnApplied 
Managerial Approach. New York: John Wiley \& Sons.

Standar Akuntansi Keuangan Syariah. (2019). Diambil kembali dari lkatan Akuntan Indonesia: http://iaiglobal.or.id/v03/standarakuntansi-keuangan/pernyataansas-68-psak-105-akuntansimudharabah

Sugiyono. (2014). Metode Penelitian Kuantitatif, Kualitatif, dan $R \& D$. Bandung: Penerbit Alfabeta.

Sutedi, A. (2009). Perbankan Syariah: Tinjauan dan Beberapa Segi Hukum. Jakarta: Ghalia Indonesia. Suwiknyo, D. (2009). Kompilasi Tafsir Ayat-Ayat Ekonomi Islam. Yogyakarta: Pustaka Pelajar.

Turban, E., Aronson, J. E., \& Liang, T.-P. (2015). Decision Suport System And Intelligent Systems. New Jersey: Pearson education.

Wangsawidjaja. (2012). Pembiayaan Bank Syariah. Jakarta: PT Gramedia.

Yaya, R., Martawireja, A. E., \& Abdurahim, A. (2009). Akuntansi Perbankan Syariah: Teori dan Praktik Kontemporer. Jakarta: Penerbit Salemba Empat. 


$$
\text { p-ISSN 2685-8401 e-ISSN 2685-7502 }
$$

(Halaman Sengaja Dikosongkan) 